\title{
Surveillance of avirulent Newcastle disease viruses at live bird markets in Eastern China during 2008-2012 reveals a new sub-genotype of class I virus
}

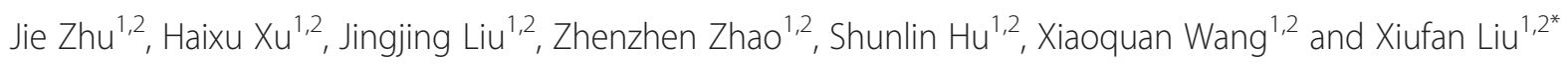

\begin{abstract}
Background: The strains of Newcastle disease virus (NDV) can be divided into two distinct clades: class I and class II. At present, limited molecular epidemiological data are available for the class I virus at live bird markets (LBMs). Knowing the genomic and antigenic characteristics of class I NDVs might provide important insights into the evolution dynamics of these viruses. In this study class I NDVs isolated from LBMs in Eastern China between 2008 and 2012 were characterized.
\end{abstract}

Results: We characterized 34 class I NDVs genetically and 15 of the 34 NDVs pathologically which originated from geese, chickens and ducks at live bird markets. Based on the older classification system, twelve of fourteen strains isolated from 2008 to 2010 belonged to sub-genotype 3b. However, the rest 22 strains formed a separate novel cluster in genotype 3, which was designated as sub-genotype 3c. When based on the new classification system, sub-genotype $3 \mathrm{~b}$ was classified into sub-genotype $1 \mathrm{a}$ and the sub-genotype $3 \mathrm{c}$ was classified into sub-genotype 1b. Over $62 \%$ (21/34) of the viruses were chicken-origin and only 13 isolates were waterfowl-origin. The Crossneutralization reactions between CKJJS/05/11, CK/JS/06/12 and the vaccine strain LaSota showed significant antigenic differences between them.

Conclusions: Currently, sub-genotype 3c (or 1b) NDVs are the most frequently isolated classl strains at LBMs in Eastern China., and the class I NDVs has transferred from waterfowls to chickens and circulated in chicken flocks extensively.

Keywords: Class I Newcastle disease virus, Sub-genotype 3c, Sub-genotype 1b, Genetic, Antigenticy

\section{Background}

Newcastle disease (ND) is caused by Newcastle disease virus(NDV)which has caused severe economic losses all around the world [1,2]. NDV is a member of avian paramyxovirus (APMV), which belongs to the genus Avulavirus, sub-family Paramyxovirinae, family Paramyxoviridae, and order Mononegavirales [3]. The genome of NDV is a single-stranded, negative-sense, nonsegmented RNA of approximately $15.2 \mathrm{~kb}$. The viral genome is comprised of six

\footnotetext{
* Correspondence: xfliu@yzu.edu.cn

'Animal Infectious Disease Laboratory, College of Veterinary Medicine, Yangzhou University, 12 East Wenhui Road, Yangzhou, Jiangsu 225009, China ${ }^{2}$ Jiangsu Co-innovation Center for Prevention and Control of Important Animal Infectious Diseases and Zoonoses, Yangzhou University, Yangzhou
} 225009, China genes: nucleocapsid (NP), phosphoprotein $(\mathrm{P})$, matrix $(\mathrm{M})$, fusion (F), hemagglutinin-neuraminidase (HN), and RNAdependent RNA polymerase (L) [4]. The strains of NDV can be divided into two distinct clades: class I and class II, and based on the older classification system, both clades could be divided into 9 genotypes, and the class II clade can be divided into fifteen genotypes when based on the new classification system, while the class I clade can be divided into three sub-genotypes [5-7].

Liu et.al has found that the class I virus strains circulating among Eastern China were genotype 2 and 3, while the genotype 3 can be divided into two sub-genotype: $3 \mathrm{a}$ and $3 \mathrm{~b}$ [8]. In 2012, one class I virus isolated in Eastern China was ascribed to genotype 4 [9], which means that

\section{Biomed Central}

(c) 2014 Zhu et al.; licensee BioMed Central Ltd. This is an Open Access article distributed under the terms of the Creative Commons Attribution License (http://creativecommons.org/licenses/by/4.0), which permits unrestricted use, distribution, and reproduction in any medium, provided the original work is properly credited. The Creative Commons Public Domain Dedication waiver (http://creativecommons.org/publicdomain/zero/1.0/) applies to the data made available in this article, unless otherwise stated. 
the class I viruses circulating in Eastern China were mix. As Liu et al. [8] only concerned about the class I virus circulating in ducks at LBMs in Eastern China, and deals of chickens were also existed at the live bird markets (LBMs), however, the circulation of the class I virus among chickens has not been well elucidated. In this study, we collected 7106 cloacal swabs from 600 flocks including both chickens and waterfowls for virus isolation from 2008 to 2012 and 34 class I isolates were characterized phylogentically while and 15 of the 34 NDVs were pathologically characterized.

\section{Results}

Isolation and identification of the NDVs from the LBMs in Eastern China

We obtained a total of 7106 samples by monthly collections from multiple avian species at LBMs in Eastern China during May 2008 to April 2012, and 247 NDVs were isolated and identified with a total isolation rate of $3.48 \%$. As is shown in Table 1, a total of $3.32 \%$ (236/7106) class I NDVs were identified and the isolation rates in colder months (from November to March) were higher than in warmer months (from April to October) which is consistent with the previous report [8]. Furthermore, the monthly isolation rate varied from 0 to $7.5 \%$ and the yearly isolation rate varied from $2.91 \%$ to $5.67 \%$ and January 2012 had the highest isolation rate although no specific thing about these times was found. The 236 class I NDVs were collected from 34 flocks (21 from the chickens and 13 from the waterfowls), and the details for these isolates were listed in Table 2.

\section{Phylogenetic analysis}

236 samples were detected to be positive in the 7106 swabs, but the result of sequences showed that the viruses isolated in the same flock were 100\% homology. At last, we have got 34 isolates in this manuscript. The F gene of the $34 \mathrm{NDV}$ from each flock were sequenced and analyzed phylogentically with 20 representative reference class I F gene sequences, and the phylogentic tree was constructed based on the variable region of the $\mathrm{F}$ genes (47-420 nt) which was shown in Figure 1.

Based on the previous classification system, all the viruses were grouped together with the Hong Kong LBM strains and the earlier Eastern China strains which have been designated as genotype $3[5,6,8]$. Except CK/JS/02/10 and $\mathrm{D} / \mathrm{JS} / 03 / 09$, all strains isolated among 2008 to 2010 were grouped together with two duck-origin virus isolated in Jiangsu and Zhejiang (D/ZJ/26/05, D/JS/1/07) that have been designated as sub-genotype $3 \mathrm{~b}[8]$. However, the rest 22strains formed a new cluster which evolutionary distance with sub-genotype 3a and 3b was 0.068 and 0.099 (Table 3), respectively. Therefore, this new cluster was separated from the two established sub-genotypes in genotype 3 and designated as sub-genotype 3c. As is shown in Figure 2, when utilized the new classification system proposed by Diel et al. [7], the 34 strains could also be clustered into two separated sub-genotypes: $1 \mathrm{a}$ and $1 \mathrm{~b}$. Meanwhile, the sub-genotype $3 \mathrm{~b}$ belonged to sub-genotype $1 \mathrm{a}$ in the new classification system and sub-genotype $3 \mathrm{c}$ belonged to subgenotype $1 b$.

The above genotypic classification of NDVs could be also reflected by comparisons of the deduced amino acid sequence of the F gene. When deduced amino acid sequences of the $\mathrm{F}$ gene of the three sub-genotypes were compared, different amino acid profiles were present between the $3 \mathrm{c}$ and the other 2 sub-genotype NDVs in genotype 3 . Three different amino acids were present between the $3 \mathrm{a}$ and $3 \mathrm{c}$ viruses of $\mathrm{F}$ gene (Table 4), and $3 \mathrm{c}$ strains displayed the substitutions W10L, E47D and V118I. As shown in Table 4, when compared with the sub-genotype $3 \mathrm{~b}$ viruses, the $3 \mathrm{c}$ viruses had the following amino acid substitutions: P6S, V19A, S36P, R48K, I69M, Q113R, I165V, T176A，I206V，F214L，S231L，V237I, Y337H, I386L, L396M, R445Q, D489N, T522A, R530K and S531A.

\section{Pathogenicity tests}

We selected 3 viruses each year to test the pathogenicity, and the results of the pathogenicity tests showed that all

Table 1 Monthly isolations of NDVs from cloacal swabs of multiple avian species at live bird markets for wholesale in Eastern China during May 2008 to April 2012

\begin{tabular}{|c|c|c|c|c|c|c|c|c|c|c|c|c|c|c|}
\hline \multirow[t]{2}{*}{ Year } & \multicolumn{12}{|c|}{ Positive/sample } & \multirow[t]{2}{*}{ Total } & \multirow{2}{*}{$\begin{array}{l}\text { Isolation } \\
\text { rate (\%) }\end{array}$} \\
\hline & Jan & Feb & Mar & Apr & May & June & July & Aug & Sep & Oct & Nov & Dec & & \\
\hline 2008 & - & - & - & - & $4 / 200$ & $8 / 180$ & $1 / 90$ & $1 / 100$ & $10 / 200$ & $0 / 100$ & $4 / 100$ & $4 / 130$ & $32 / 1100$ & 2.91 \\
\hline 2009 & $8 / 200$ & $8 / 180$ & $5 / 100$ & $5 / 140$ & $1 / 100$ & $5 / 130$ & 0/130 & $1 / 160$ & $2 / 130$ & $7 / 200$ & $4 / 110$ & $5 / 120$ & $51 / 1700$ & 3.00 \\
\hline 2010 & $9 / 160$ & $7 / 150$ & $11 / 180$ & $5 / 140$ & $1 / 100$ & $5 / 130$ & $0 / 140$ & $1 / 140$ & $2 / 180$ & 7/190 & $4 / 150$ & $5 / 140$ & $57 / 1800$ & 3.16 \\
\hline 2011 & $11 / 180$ & $5 / 160$ & $8 / 180$ & $7 / 140$ & $5 / 100$ & $2 / 130$ & $0 / 150$ & $0 / 130$ & $4 / 150$ & $5 / 160$ & $2 / 175$ & $7 / 145$ & $56 / 1800$ & 3.11 \\
\hline 2012 & $15 / 200$ & $13 / 180$ & $10 / 150$ & $10 / 176$ & - & - & - & - & - & - & - & - & $40 / 706$ & 5.67 \\
\hline total & $43 / 740$ & $33 / 670$ & $34 / 610$ & $27 / 596$ & $11 / 500$ & $20 / 570$ & $1 / 510$ & $3 / 530$ & $18 / 660$ & $19 / 650$ & $14 / 535$ & $21 / 535$ & & \\
\hline Isolation Rate (\%) & 5.81 & 4.93 & 5.57 & 4.53 & 2.20 & 3.51 & 0.200 & 0.57 & 2.73 & 2.92 & 2.62 & 3.93 & & 3.32 \\
\hline
\end{tabular}


Table 2 Details of the representative NDVs isolated from the domestic avian species at LBMs in Eastern China during 2008 to 2012

\begin{tabular}{|c|c|c|c|c|c|c|c|c|c|}
\hline Virus strains & Year of isolation & Location (Province) & Host & ICPI & MDT & $\begin{array}{l}\text { Cleavage site of } \\
\text { fusion protein }\end{array}$ & Class & subgenotype & $\begin{array}{l}\text { Accession } \\
\text { number }\end{array}$ \\
\hline $\mathrm{D} / \mathrm{JS} / 1 / 08$ & 2008 & Jiangsu & Duck & 0 & $>120 \mathrm{~h}$ & EQQERL & I & $3 b$ & KM509016 \\
\hline $\mathrm{CK} / \mathrm{AH} / 02 / 08$ & 2008 & Anhui & Chicken & 0 & $>120 \mathrm{~h}$ & EQQERL & I & $3 b$ & KM509017 \\
\hline Go/SD/03/08 & 2008 & Shandong & Goose & 0 & $>120 \mathrm{~h}$ & EQQERL & । & $3 b$ & KM509018 \\
\hline CK/HeN/04/08 & 2008 & Henan & Chicken & $N T^{a}$ & NT & EQQERL & । & $3 b$ & KM509019 \\
\hline Go/JS/01/09 & 2009 & Jiangsu & Goose & 0 & $>120 \mathrm{~h}$ & EQQGRL & । & $3 b$ & KM509020 \\
\hline Go/JS/02/09 & 2009 & Jiangsu & Goose & 0 & $>120 \mathrm{~h}$ & EQQERL & । & $3 b$ & KM509021 \\
\hline D/JS/03/09 & 2009 & Jiangsu & Duck & 0 & $>120 \mathrm{~h}$ & ERQERL & I & $3 c$ & KM509022 \\
\hline D/JS/04/09 & 2009 & Jiangsu & Duck & NT & NT & EQQERL & । & $3 b$ & KM509023 \\
\hline CKJS/05/09 & 2009 & Jiangsu & Chicken & NT & NT & EQQERL & I & $3 b$ & KM509024 \\
\hline CK/SD/06/09 & 2009 & Shandong & Chicken & NT & NT & EQQERL & I & $3 b$ & KM509025 \\
\hline D/JS/01/10 & 2010 & Jiangsu & Duck & 0 & $>120 \mathrm{~h}$ & EQQERL & I & $3 b$ & KM509026 \\
\hline CKJJS/02/10 & 2010 & Jiangsu & Chicken & 0 & $>120 \mathrm{~h}$ & ERQERL & । & $3 c$ & KM509027 \\
\hline CKJS/03/10 & 2010 & Jiangsu & Chicken & 0 & $>120 \mathrm{~h}$ & EQQERL & I & $3 b$ & KM509028 \\
\hline CKJJS/04/10 & 2010 & Jiangsu & Chicken & NT & NT & EQQERL & I & $3 b$ & KM509029 \\
\hline $\mathrm{D} / \mathrm{SH} / 05 / 10$ & 2010 & Shanghai & Duck & NT & NT & EQQERL & I & $3 b$ & KM509030 \\
\hline CKJJS/06/10 & 2010 & Jiangsu & Chicken & NT & NT & ERQERL & I & $3 b$ & KM509031 \\
\hline Go/JS/01/11 & 2011 & Jiangsu & Gose & 0 & $>120 \mathrm{~h}$ & ERQERL & I & $3 c$ & KM509032 \\
\hline CKJJS/02/11 & 2011 & Jiangsu & Chicken & 0 & $>120 \mathrm{~h}$ & ERQERL & I & $3 c$ & KM509033 \\
\hline CKJSS/03/11 & 2011 & Jiangsu & Chicken & 0 & $>120 \mathrm{~h}$ & ERQERL & I & $3 c$ & KM509034 \\
\hline CKJJS/04/11 & 2011 & Jiangsu & Chicken & NT & NT & ERQERL & । & $3 c$ & KM509035 \\
\hline CKJS/05/11 & 2011 & Jiangsu & Chicken & NT & NT & ERQERL & I & $3 c$ & KM509036 \\
\hline CKJS/06/11 & 2011 & Jiangsu & Chicken & NT & NT & ERQERL & I & $3 c$ & KM509037 \\
\hline CKJJS/07/11 & 2011 & Jiangsu & Chicken & NT & NT & ERQERL & I & $3 c$ & KM509038 \\
\hline CKJS/08/11 & 2011 & Jiangsu & Chicken & NT & NT & ERQERL & I & $3 c$ & KM509039 \\
\hline D/JS/01/12 & 2012 & Jiangsu & Duck & NT & NT & ERQERL & 1 & $3 c$ & KM509040 \\
\hline D/JS/02/12 & 2012 & Jiangsu & Duck & 0 & $>120 \mathrm{~h}$ & ERQERL & I & $3 c$ & KM509041 \\
\hline CKJS/03/12 & 2012 & Jiangsu & Chicken & 0 & $>120 \mathrm{~h}$ & ERQERL & I & $3 c$ & KM509042 \\
\hline CKJS/04/12 & 2012 & Jiangsu & Chicken & 0 & $>120 \mathrm{~h}$ & ERQERL & I & $3 c$ & KM509043 \\
\hline CKJJS/05/12 & 2012 & Jiangsu & Chicken & NT & NT & ERQERL & I & $3 c$ & KM509044 \\
\hline CKJJS/06/12 & 2012 & Jiangsu & Chicken & NT & NT & ERQERL & I & $3 c$ & KM509045 \\
\hline Go/JS/07/12 & 2012 & Jiangsu & Goose & NT & NT & ERQERL & । & $3 c$ & KM509046 \\
\hline Go/SH/08/12 & 2012 & Shanghai & Goose & NT & NT & ERQERL & I & $3 c$ & KM509047 \\
\hline CK/HeN/09/12 & 2012 & Henan & Chicken & NT & NT & ERQERL & I & $3 c$ & KM509048 \\
\hline CK/SD/10/12 & 2012 & Shandong & Chicken & NT & NT & ERQERL & I & $3 c$ & KM509049 \\
\hline
\end{tabular}

${ }^{\mathrm{a} N T}$ : not test.

the selected isolates had an intracerebral pathogenicity index value 0 and a mean death time $>120 \mathrm{~h}$, which was consistent with the tyipical avirulent motif ${ }^{112} \mathrm{EQ} /$ RQERL ${ }^{117}$ at the F cleavage sites.

\section{Antigenic difference assays}

As is shown in Table 5, cross-neutralization and -hemagglutination inhibition reactions between the two isolates confirmed the significant antigenic differences between the isolates and vaccine strain. In the neralization test, the $\mathrm{R}$ value between the CK/JS/05/11 and CK/JS/06/12 and LaSota were only 0.17 and 0.12 , respectively. When $0.67 \leq R \leq 1.5$, indicates no significant antigenic difference between the two viruses and $0.5 \leq R \leq 0.67$ indicates a minor difference between the two viruses. An $\mathrm{R}$ value of $R<0.5$ indicates a major difference between the two virus strains. 


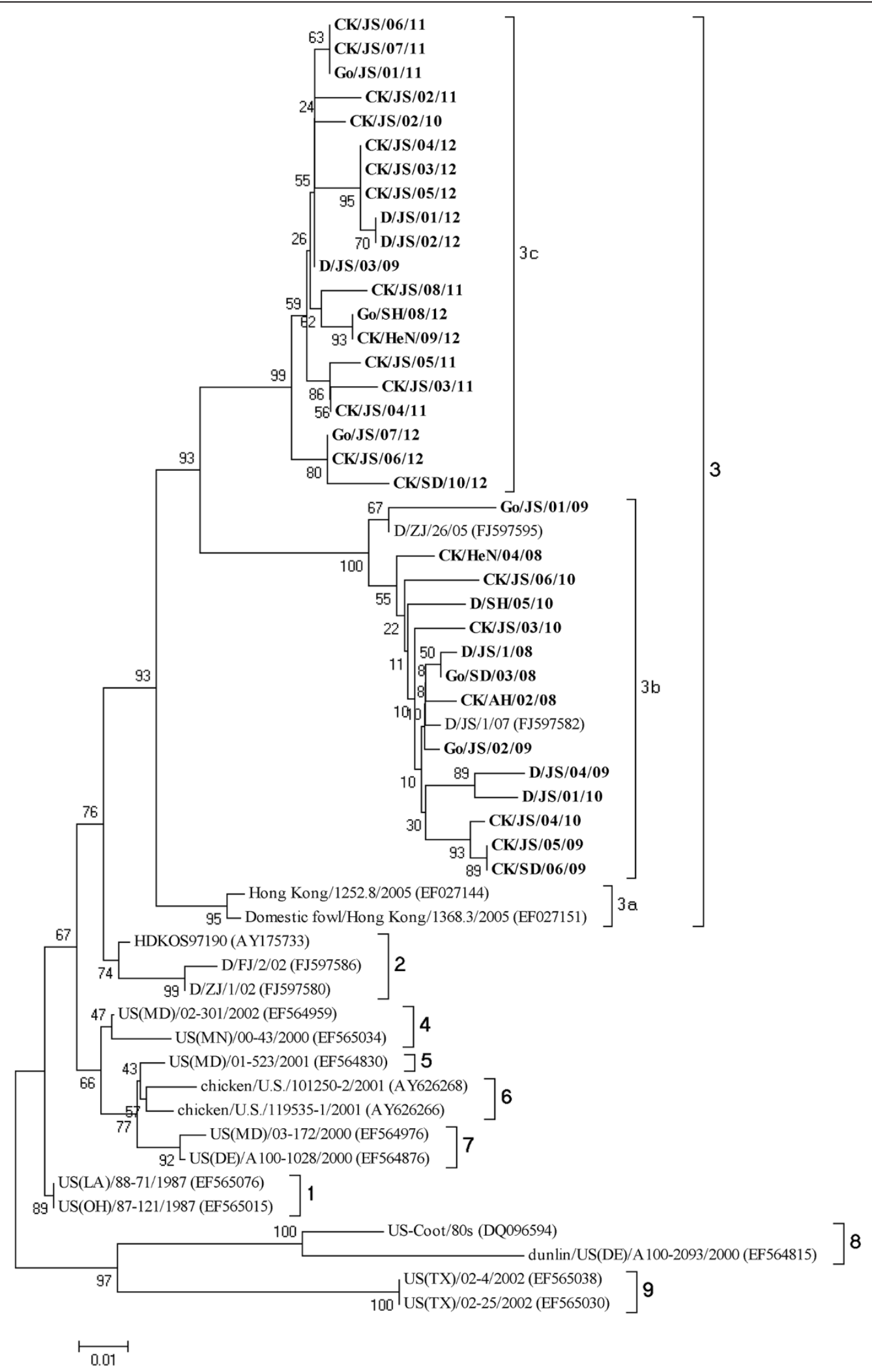

Figure 1 Phylogenetic tree of class I NDV isolatess based on the older classification methods by the variable region (nt 47-420) of the F gene. The reference class I NDV isolates characterized in this study were shown in bold. 


$\begin{aligned} & \text { Table } 3 \text { Estimation of evolutionary distances between } \\
& \text { sub-genotypes of genotype } \mathbf{3}\end{aligned}$
\begin{tabular}{llll}
\hline $\begin{array}{l}\text { Sub- } \\
\text { genotype }\end{array}$ & Evolutionary distances \\
\cline { 2 - 4 } & $\mathbf{3 a}$ & $\mathbf{3 b}$ & $\mathbf{3 c}$ \\
\hline $3 \mathrm{~b}$ & 0.021 & 0.016 \\
$3 \mathrm{~b}$ & 0.101 & & 0.020 \\
$3 \mathrm{c}$ & 0.068 & 0.099 & \\
\hline
\end{tabular}

\section{Discussion}

Currently, most of the avirulent NDVs isolated from the LBMs in America and Korea belonged to class I clade. [10-12]. Liu et.al have reported that the class I viruses circulated in waterfowls from 2002 to 2007 at LBMs in Eastern China were genotype 2 and 3 which could be divided into two separated groups: $3 \mathrm{a}$ and $3 \mathrm{~b}$ [8]. In this paper, we conducted the continuous surveillance and characterization of class I clade NDVs both from the chicken and waterfowl flocks at LBMs in Eastern China during 2008 to 2012 and found a new separate cluster in genotype 3 which possessed its own characteristic amino acid substitutions on the F protein (Tables 1 and 2).

During May 2008 to April 2012, 247 NDVs were isolated from the LBMs in Eastern China and 95.5\% (236/ 247) were class I NDVs, which indicated that the class I NDVs were still frequently isolated among the birds at LBMs. Researchers have already ensured that the class I clade NDVs mainly circulated among waterfowls $[5,6,8]$, however in this research, 21 of the 34 classI NDVpositive flocks were the chicken-origin, which indicates that the cross-species transmission has been appeared and class I NDVs have already become frequently isolated among the chickens. In china, deals of chickens and waterfowls are made together at the LBMs, therefore the LBM has been one of the important sites for pathogens inter- or cross-species transmission. Considering the higher isolation of the class I NDVs at the LBMs, much attention should be paid to the transmission of class I NDV at this site.

All the isolates in this study were clustered into genotype 3 which was divided into two sub-genotypes 3a and $3 \mathrm{~b}$ in the previous study $[6,8]$. However, a separate cluster was identified here based on the phylogenetic analysis of the partial F genes. As is illustrated by Diel et al. [7], different genotypes should have an average distance per site $>10 \%(0.1)$ and different sub-genotypes should have an average distance per site between $3(0.03)$ and $10 \%(0.1)$, while its evolutionary distance with $3 \mathrm{a}$ and $3 \mathrm{~b}$ was 0.068 and 0.099 , respectively, which has met the requirement to form a new sub-genotype and was designated here as 3c. Based on the two classification methods, the isolates from 2008-2010 are more similar to older previously studied isolates and the more recent strains (2011-2012) are clustering together and the waterfowl-origin isolation rate is higher than the 2011-2012 isolation rate, which means that the class I NDV is keeping evolution in the poultry flocks and can affect the chickens more efficiency. Comparing the partial $\mathrm{F}$ genes between the three sub-genotypes, we found that the sub-genotype $3 \mathrm{a}$ and $3 \mathrm{c}$ shared the same cleavage site EQQERL and $3 \mathrm{c}$ viruses showed both higher nucleotide and amino acid homologous with sub-genotype $3 \mathrm{a}$ when compared with $3 \mathrm{~b}$. Therefore the sub-genotype $3 \mathrm{c}$ viruses might evolve from the sub-genotype 3a.

Previously, seven neutralizing epitopes positioned at residues $72,74,75,78,79,157$ to 171 , and 343 of the $F$ protein have been identified [13-16]. When compared the F genes of $3 c$ cluster with the vaccine strain LaSota, four of these epitopes were changed as follows: A75Q, A79S, V168I, and D170S, which displayed the antigenic difference between them and was confirmed by the results derived from the cross-HI and -neutralization tests in this study. Class I NDVs are the avirulent strains usually isolated from waterfowls $[5,8]$, however, $\mathrm{Yu}$ et. al found that the class I avirulent virus could be generated into virulent one through consecutive passages in the chicken only by two residues alteration at the F cleavage site [17]. As is reported that, the virulent class I viruses which were phylogenetically closely related to those found in WS have previously been found [18,19], and the risk of ND epidemic would be introduced due to its high infection rate in the poultry flocks, the significant antigenic difference and low genetic homology with the vaccine strain [20]. Therefore, continuous surveillance for the class I NDVs both from the LBMs and poultry farms should be performed and strict control strategies should be developed to eliminate the potential risk caused by these NDVs.

\section{Conclusions}

The NDVs isolated at LBMs during 2008-2012 belonged to sub-genotype $3 \mathrm{~b}$ (or 1a), and a newly identified cluster 3c (or 1b) which has already transferred from waterfowls to terrestrial birds and has been frequently isolated in the chicken flocks extensively.

\section{Materials and methods}

\section{Virus isolation and identification}

We collected cloacal swab samples from the LBMs in Eastern China (Figure 3) since 2008 to 2012, and each flocks we collected 5-15 samples. And all the swabs were inoculated into the allantoic cavities of 9 to 11 day old specific-pathogen-free (SPF) chicken embryos and incubated at $37^{\circ} \mathrm{C}$ for two passages of 96 hours each [6]. Allantoic fluids from the incubated eggs were harvested after the completion of two passages and were then assayed for hemagglutination activity (HA) by following the OIE protocols for NDV; the presence of NDV was confirmed by hemagglutination inhibition (HI) assay 


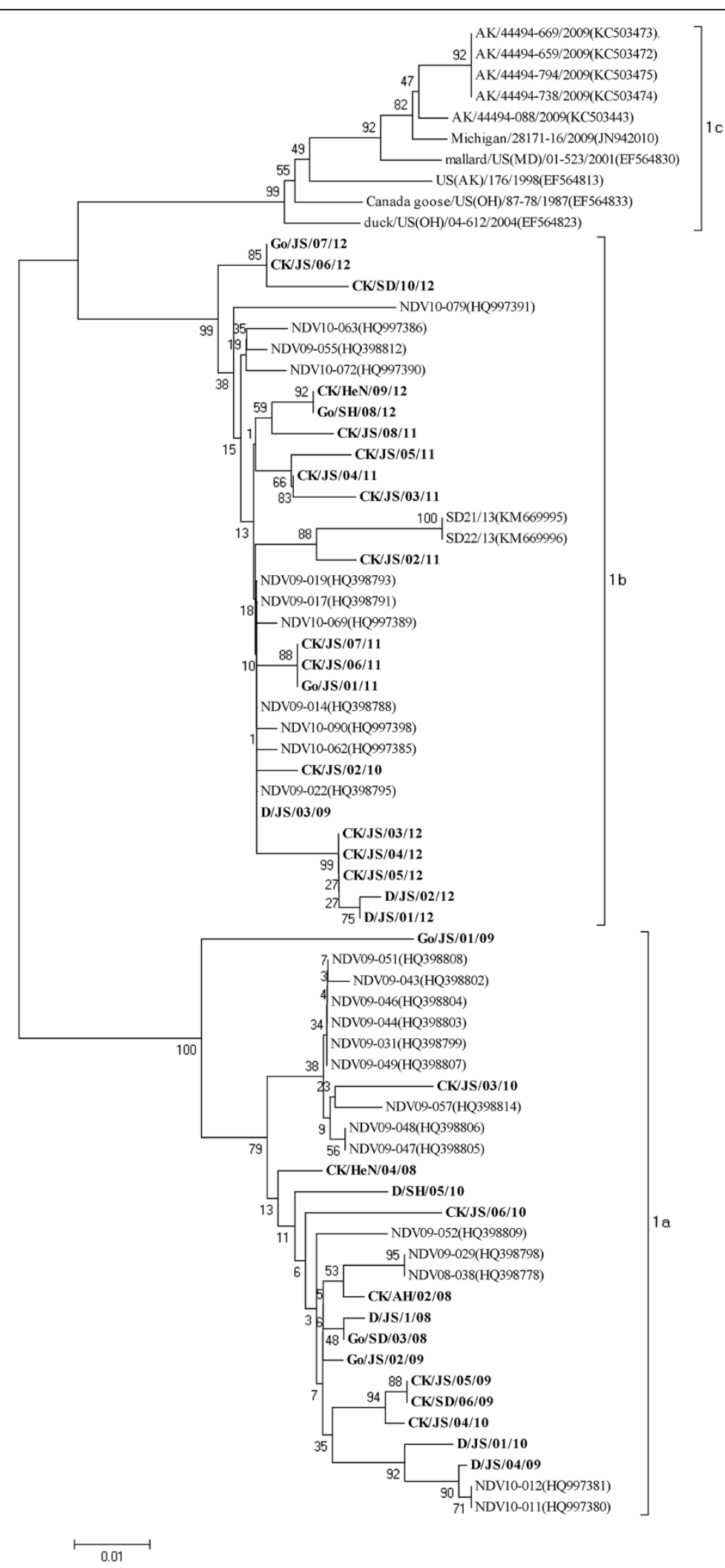

Figure 2 Phylogenetic tree of class I NDV isolatess based on the new classification methods by the complete sequence the F genes. The reference class I NDV isolates characterized in this study were shown in bold. 
Table 4 Subtype-specific residue substitutions in the deduced genotype $3 \mathrm{~F}$ protein sequence

\begin{tabular}{|c|c|c|c|c|c|c|c|c|c|c|c|c|c|c|c|c|c|c|c|c|c|c|c|c|c|c|}
\hline \multirow{2}{*}{$\begin{array}{l}\text { Sub- } \\
\text { genotypes }\end{array}$} & 6 & 10 & 12 & 18 & 19 & 22 & 36 & 47 & 48 & 69 & 113 & 118 & 165 & 176 & 206 & 214 & 231 & 237 & 337 & 386 & 396 & 445 & 489 & 522 & 530 & 531 \\
\hline & $S$ & $\mathbf{L}$ & A & $\mathbf{v}$ & A & $S$ & $\mathbf{P}$ & D & $\mathrm{K}$ & $M$ & $\mathbf{R}$ & $I$ & v & A & v & L & L & $\mathbf{i}$ & $\mathrm{H}$ & $\mathbf{L}$ & $M$ & $\mathbf{Q}$ & $\mathrm{N}$ & A & $\mathrm{K}$ & A \\
\hline $3 a$ & $-^{a}$ & $W$ & V & - & - & L/- & - & $E$ & - & - & - & - & $N T^{b}$ & NT & NT & NT & NT & NT & NT & NT & NT & NT & NT & NT & NT & NT \\
\hline $3 b$ & P/- & - & T/- & $M$ & V & - & S/- & - & $\mathrm{R}$ & 1 & Q & - & 1 & $\mathrm{~T}$ & 1 & $\mathrm{~F}$ & $S$ & V & $Y$ & 1 & $L$ & $\mathrm{R}$ & $D$ & $\mathrm{~T}$ & $\mathrm{R}$ & $S$ \\
\hline $3 c$ & - & - & V/- & L/- & T/- & - & $\mathrm{Q} /-$ & - & - & - & - & V & L/- & - & G/- & - & - & - & - & - & - & - & - & - & - & - \\
\hline
\end{tabular}

a-indicates genetic identity with the consensus residue.

${ }^{\mathrm{b} N T: \text { not test. }}$ 
Table 5 Coefficients of antigenic similarity (R) between NDV isolates and LaSota strain

\begin{tabular}{ll}
\hline Strain & LaSota \\
\hline CKJJS/05/11 & $0.24^{\mathrm{a}} 0.17^{\mathrm{b}}$ \\
CKJJS/06/12 & $0.27^{\mathrm{a}} 0.12^{\mathrm{b}}$ \\
\hline
\end{tabular}

${ }^{\mathrm{a} C r o s s-h e m a g g l u t i n a t i o n ~ i n h i b i t i o n ~ t e s t . ~}$

${ }^{\mathrm{b}}$ Chicken embryo cross-neutralization test.

with NDV-specific polyclonal antiserum [21]. The NDV isolates obtained from the surveillance that were selected for pathogenicity tests and genetic studies are presented in Table 2.

\section{Viral RNA exaction}

Virus RNA extraction was prepared from infective allantoic fluid using TRIzol LS (Invitrogen, Carlsbad, California, USA) according to the manufacturer's instructions. The RNA pellets were resuspended in RNase-free water after washing with $70 \%$ ethanol and were stored at $-70^{\circ} \mathrm{C}$ until use. And the initial RT reaction was performed as described previously [22].

\section{Sequencing of the partial $\mathrm{F}$ genes}

According to the published $\mathrm{F}$ gene sequences from the GenBank database, we designed a pair of primers for the amplification of the partial F genes: FTY1: CGTAGAAAA AACACGGGTAGAAGA (nt 4494-4517), FTY2: CAGGTAGGTRGCACGCATATTATT (5429-5452). The DNA amplification was performed for 25 cycles consisting of 30 seconds at $94^{\circ} \mathrm{C}, 1 \mathrm{~min}$ at $58^{\circ} \mathrm{C}$, and followed by a final elongation of $10 \mathrm{~min}$ at $72^{\circ} \mathrm{C}$. The complete $\mathrm{F}$ genes were amplified by the primes designed by Liu et al. [8]. The PCR products were sequenced at Sangon (Shanghai, China).

\section{Phylogenetic analysis and inference of the evolutionary distances}

In this study, we obtained class I reference NDV F gene sequences representing previously class I genotypes 1 to 9 based on the previously established classification system and reference strains representing the newly established classification system as $1 \mathrm{a}, 1 \mathrm{~b}$ and $1 \mathrm{c}$ from the Genbank, while the accession numbers of these NDVs were shown in the phylogenetic trees. The prediction of amino acid sequences, alignment of sequences, and phylogenetic analysis were performed using MegAlign in the Lasergene package (DNASTAR Inc. Madison, WI, U. S.). Phylogenetic tree was created using the neighborjoining method and MEGA 5.2 based on comparison of partial F gene sequences (between nt 47 and 420). The evolutionary distances were inferred by the software MEGA5 and the mean interpopulational evolutionary diversity (mean evolutionary distance between genotypes) was determined using the Maximum Composite Likelihood model $[7,23]$.

\section{Pathogenicity tests}

The intracerebral pathogenicity index in 1-day-old chicks and the mean death time in 9 to 11-day-old SPF chicken embryos were determined for some of the isolates in this study as Liu did previously [2].

Figure 3 Map of China showing Shanghai and Shandong, Henan, Anhui, Jiangsu provinces where sampling birds came from during the NDV surveillance program at LBMs. 


\section{Comparision of the antigenic difference between the isolates and vaccine strain}

The anti-serum against CK/JS/06/12, CK/JS/05/11 and LaSota were prepared from the SPF chickens vaccinated with inactivated oil-emulsion LaSota, CK/JS/06/12 and CK/ JS/05/11, respectively. Three weeks post-vaccination, serum were collected and stored at $-70^{\circ} \mathrm{C}$ until use. The cosshaemagglutination inhibition (HI) and cross-neutralization tests to measure the antigenic difference between the isolates and the vaccination strain LaSota, were performed as described previously [24].

\section{Competing interests}

The authors declare that they have no competing interests.

\section{Authors' contributions}

Z carried out the study design, phylogenetic analysis, sequence alignment, and drafted the manuscript. HX contributed for RNA preparation and RT-PCR. JL, ZZ participated in the whole procedure of the virus isolation and pathogenicity tests. $\mathrm{SH}, \mathrm{XW}$ contributed to the design of the study and revision of the manuscript. XL conceived of the study, provided consultation and coordination, and helped to draft the manuscript. All authors read and approved the final manuscript.

\section{Acknowledgements}

This work was supported by Chinese Special Fund for Agro-Scientific Research in the Public Interest (201303033, 201003012), the Earmarked Fund for Modern Agro-Industry Technology Research System (nycytx-41-G07), National Natural Science Foundation of China (31172338), and the Priority Academic Program Development of Jiangsu Higher Education Institutions (PAPD).

Received: 15 September 2014 Accepted: 21 November 2014 Published online: 04 December 2014

\section{References}

1. Alexander DJ: Newcastle disease and other avian paramyxoviruses. Rev Sci Tech 2000, 19:443-462.

2. Liu XF, Wan HQ, Ni XX, Wu YT, Liu WB: Pathotypical and genotypical characterization of strains of Newcastle disease virus isolated from outbreaks in chicken and goose flocks in some regions of China during 1985-2001. Arch Virol 2003, 148:1387-1403.

3. Mayo MA: A summary of taxonomic changes recently approved by ICTV. Arch Virol 2002, 147:1655-1663.

4. Kattenbelt JA, Stevens MP, Gould AR: Sequence variation in the Newcastle disease virus genome. Virus Res 2006, 116:168-184.

5. Kim LM, King DJ, Curry PE, Suarez DL, Swayne DE, Stallknecht DE, Slemons RD, Pedersen JC, Senne DA, Winker K, Afonso CL: Phylogenetic diversity among low-virulence newcastle disease viruses from waterfowl and shorebirds and comparison of genotype distributions to those of poultry-origin isolates. J Virol 2007, 81:12641-12653.

6. Kim LM, King DJ, Suarez DL, Wong CW, Afonso CL: Characterization of class I Newcastle disease virus isolates from Hong Kong live bird markets and detection using real-time reverse transcription-PCR. J Clin Microbiol 2007, 45:1310-1314

7. Diel DG, da Silva LH, Liu H, Wang Z, Miller PJ, Afonso CL: Genetic diversity of avian paramyxovirus type 1: proposal for a unified nomenclature and classification system of Newcastle disease virus genotypes. Infect Genet Evol 2012, 12:1770-1779.

8. Liu X, Wang X, Wu S, Hu S, Peng Y, Xue F: Surveillance for avirulent Newcastle disease viruses in domestic ducks (Anas platyrhynchos and Cairina moschata) at live bird markets in Eastern China and characterization of the viruses isolated. Avian Pathol 2009, 38:377-391.

9. Meng C, Qiu X, Jin S, Yu S, Chen H, Ding C: Whole genome sequencing and biological characterization of Duck/JS/10, a new lentogenic class I Newcastle disease virus. Arch Virol 2012, 157:869-880.
10. Choi KS, Lee EK, Jeon WJ, Kwon JH, Lee JH, Sung HW: Molecular epidemiologic investigation of lentogenic Newcastle disease virus from domestic birds at live bird markets in Korea. Avian Dis 2012, 56:218-223.

11. King DJ, Seal BS: Biological and molecular characterization of Newcastle disease virus isolates from surveillance of live bird markets in the northeastern United States. Avian Dis 1997, 41:683-689.

12. Seal BS, Wise MG, Pedersen JC, Senne DA, Alvarez R, Scott MS, King DJ, Yu Q, Kapczynski DR: Genomic sequences of low-virulence avian paramyxovirus-1 (Newcastle disease virus) isolates obtained from live-bird markets in North America not related to commonly utilized commercial vaccine strains. Vet Microbiol 2005, 106:7-16.

13. Neyt C, Geliebter J, Slaoui M, Morales D, Meulemans G, Burny A: Mutations located on both F1 and F2 subunits of the Newcastle disease virus fusion protein confer resistance to neutralization with monoclonal antibodies. J Virol 1989, 63:952-954.

14. Toyoda T, Gotoh B, Sakaguchi T, Kida H, Nagai Y: Identification of amino acids relevant to three antigenic determinants on the fusion protein of Newcastle disease virus that are involved in fusion inhibition and neutralization. J Virol 1988, 62:4427-4430.

15. Yusoff K, Nesbit M, McCartney H, Meulemans G, Alexander DJ, Collins MS, Emmerson PT, Samson AC: Location of neutralizing epitopes on the fusion protein of Newcastle disease virus strain Beaudette C. J Gen Virol 1989, 70(Pt 11):3105-3109.

16. Meulemans G, Gonze M, Carlier MC, Petit P, Burny A, Long L: Protective effects of $\mathrm{HN}$ and $\mathrm{F}$ glycoprotein-specific monoclonal antibodies on experimental Newcastle disease. Avian Pathol 1986, 15:761-768.

17. Shengqing $Y$, Kishida N, Ito H, Kida H, Otsuki K, Kawaoka Y, Ito T: Generation of velogenic Newcastle disease viruses from a nonpathogenic waterfowl isolate by passaging in chickens. Virology 2002, 301:206-211.

18. Alexander DJ, Campbell G, Manvell RJ, Collins MS, Parsons G, McNulty MS: Characterisation of an antigenically unusual virus responsible for two outbreaks of Newcastle disease in the Republic of Ireland in 1990. Vet Rec 1992, 130:65-68.

19. Gould AR, Kattenbelt JA, Selleck P, Hansson E, Della-Porta A, Westbury HA: Virulent Newcastle disease in Australia: molecular epidemiological analysis of viruses isolated prior to and during the outbreaks of 1998-2000. Virus Res 2001, 77:51-60.

20. Miller PJ, King DJ, Afonso CL, Suarez DL: Antigenic differences among Newcastle disease virus strains of different genotypes used in vaccine formulation affect viral shedding after a virulent challenge. Vaccine 2007, 25:7238-7246.

21. Kim LM, King DJ, Guzman H, Tesh RB, da Rosa AP T, Bueno R Jr, Dennett JA, Afonso CL: Biological and phylogenetic characterization of pigeon paramyxovirus serotype 1 circulating in wild North American pigeons and doves. J Clin Microbiol 2008, 46:3303-3310.

22. Wu S, Wang W, Yao C, Wang X, Hu S, Cao J, Wu Y, Liu W, Liu X: Genetic diversity of Newcastle disease viruses isolated from domestic poultry species in Eastern China during 2005-2008. Arch Virol 2010, 156:253-261.

23. Tamura K, Kumar S: Evolutionary distance estimation under heterogeneous substitution pattern among lineages. Mol Biol Evol 2002, 19:1727-1736.

24. Alexander DJ: Manual of diagnostic tests and vaccines for terrestrial animals, Office of International Des Epizooties. Volume 5th edition. Paris: World Organisation for Animal Health; 2004:270-282.

doi:10.1186/s12985-014-0211-2

Cite this article as: Zhu et al:: Surveillance of avirulent Newcastle disease viruses at live bird markets in Eastern China during 2008-2012 reveals a new sub-genotype of class I virus. Virology Journal 2014 11:211. 